\title{
Perlindungan Hukum Pemegang Jaminan Fidusia Atas Dirampasnya Objek Jaminan Dalam Perkara Korupsi
}

\author{
Reza Zulfikar \\ Program Magister Ilmu Hukum Universitas Lambung Mangkurat \\ Jln. Brigjend H. Hasan Basry Banjarmasin Kalimantan Selatan 70123 Indonesia \\ reza.lawfirm@gmail.com
}

Received: 22 Juni 2021; Accepted: 24 November 2021; Published: 31 Januari 2022

DOI: 10.20885/iustum.vol29.iss1.art3

\begin{abstract}
This study aims to analyze the legal status of the object of fiduciary guarantees and legal guarantees of rights holders against objects of collateral that are confiscated by the state for payment of compensation money through court decisions on corruption committed by debtors. The research uses a normative legal research method with statutory and case approaches. The results of the study conclud that first, based on the $n$ Droite De Suite nature of the object of fiduciary security, there is legal certainty in which the ownership status of the object of guarantee remains with the fiduciary recipient. However, due to corruption committed by the fiduciary guarantee provider, the ownership status of the object of this guarantee is transferred to the state and eliminates the rights of the fiduciary guarantee recipient. Second, legal protection for fiduciary guarantee holders when the object of guarantee is seized by the state in corruption cases is in the form of legal effort through civil lawsuits. Recommendations for these problems include first, the court for corruption is expected to seek to provide legal guarantees and protection to creditors who have good intentions so that later they do not lose their claim rights to debtors. Second, to revise the Fiduciary Guarantee Law for a clear legal formulation related to the legal protection process for creditors for fiduciary guarantee objects seized by the state for payment of replacement money in criminal cases, especially corruption.
\end{abstract}

Key Words: Fiduciary guarantee; corruption; legal protection

\section{Abstrak}

Penelitian ini ditujukan untuk menganalisis status hukum objek jaminan fidusia dan jaminan hukum pemegang hak terhadap objek jaminan yang dirampas oleh negara untuk pembayaran uang pengganti melalui putusan pengadilan tindak pidana korupsi yang dilakukan debitur. Penelitian menggunakan metode penelitian hukum normatif dengan pendekatan perundang-undangan dan pendekatan kasus. Hasil penelitian menyimpukan, pertama, berdasarkan sifat Droite De Suite objek jaminan fidusia, terdapat kepastian hukum sehingga status kepemilikan objek jaminan tetap pada penerima fidusia. Namun, akibat korupsi yang dilakukan pemberi jaminan fidusia, maka status kepemilikan objek jaminan ini beralih kepada negara dan menghilangkan hak penerima jaminan fidusia. Kedua, jaminan hukum pemegang jaminan fidusia ketika objek jaminan dirampas oleh negara dalam perkara korupsi yakni berupa perlindungan hukum melalui gugatan perdata. Rekomendasi atas permasalahan tersebut antara lain, pertama, pengadilan tindak pidana korupsi diharapkan mengupayakan pemberian jaminan dan perlindungan hukum terhadap kreditur yang memiliki itikad baik agar nantinya tidak kehilangan hak tagih kepada debitur. Kedua, agar dilakukan revisi terhadap Undang-Undang Jaminan Fidusia demi formulasi hukum yang jelas terkait proses perlindungan hukum terhadap kreditur atas objek jaminan fidusia yang dirampas oleh negara untuk pembayaran uang pengganti dalam perkara tindak pidana khususnya korupsi.

Kata-kata Kunci: Jaminan fidusia; korupsi; perlindungan hukum 


\section{Pendahuluan}

Jaminan fidusia merupakan hak jaminan yang diberikan kepada si berpiutang oleh si berutang atas benda bergerak yang berwujud, atau tidak berwujud dan benda tidak bergerak yang tidak dapat dibebani dengan hak tanggungan miliknya, untuk pelunasan suatu utang tertentu sebagaimana Pasal 1 angka 2 UU No. 42 Tahun 1999 tentang Jaminan Fidusia (UUJF). Pengertian tersebut, tidak hanya menjelaskan mengenai hak jaminan, tetapi sekaligus mengenai objek jaminan fidusia, yang dibebankan atas benda bergerak baik, yang berwujud maupun yang tidak berwujud dan benda tidak bergerak yang tidak dapat dibebani dengan hak tanggungan. Akan tetapi, UUJF belum memberikan suatu penyelesaian perbedaan pandangan mengenai sifat, jenis, serta karakter hak fidusia ini sebagai hak kebendaan atau hak perseorangan. Dalam hal objek jaminan fidusia yang dirampas oleh negara, untuk diperhitungkan sebagai pidana pembayaran uang pengganti dalam perkara tindak pidana korupsi, yang dilakukan oleh debitur, yang mana pihak debitur (pemberi jaminan fidusia) atas objek jaminan fidusia tersebut dirampas oleh negara dan tidak dikembalikan kepada pihak kreditur (penerima jaminan fidusia), dikarenakan objek yang dijadikan jaminan fidusia tersebut diperoleh dari harta kekayaan yang berasal dari tindak pidana korupsi.

Tidak adanya ketentuan yang menyebutkan apabila objek jaminan fidusia berasal atau digunakan untuk kejahatan dan dirampas untuk negara, memunculkan ketidakpastian bagaimana kedudukan dari objek jaminan tersebut, dan bagaimana kewajiban pemberi fidusia selanjutnya serta bagaimana hak dari penerima objek jaminan selanjutnya. Hal tersebut memperlihatkan tidak adanya kejelasan yang menyatakan pemberian ganti rugi seketika kepada penerima fidusia dan lain sebagainya sebagai akibat dari perbuatan melanggar hukum pihak debitur pemberi fidusia. ${ }^{1}$ Sebagaimana terjadi dalam Putusan Pengadilan Tindak Pidana Korupsi pada Pengadilan Negeri Palangkaraya Nomor 35/Pid.Sus-TPK/2017/PNPlk, yang dalam perkara terdakwa Cornedy, A.Md Bin Salampak W Conrad, dimana pengadilan memutuskan ada beberapa benda objek

${ }^{1}$ I Made Sarjana, Desak Putu Dewi Kasih, I Gusti Ayu Kartika, Menguji Asas Droit De Suit Dalam Jaminan Fidusia, Artikel dalam Udayana Master Law Journal Volume. 4 Nomor. 3, September 2015, Magister Hukum Udayana, Denpasar, hlm. 430. 
jaminan fidusia yang dirampas untuk negara sebagai pidana pembayaran uang pengganti atas sanksi tindak pidana yang dilakukan oleh terdakwa, dimana terdakwa adalah pemberi jaminan fidusia terhadap kreditur. Perampasan objek jaminan fidusia tersebut memberikan konsekuensi yuridis yang merugikan penerima fidusia, karena peralihan obyek fidusia menyebabkan hilangnya hak kepemilikan yang dimiliki kreditur untuk mengeksekusi benda tersebut serta kedudukan benda yang dirampas negara menjadi milik negara dan benda tersebut tidak dapat dipergunakan oleh siapapun. ${ }^{2}$ Keadaan tersebut menjadikan penerima jaminan fidusia tidak dapat pemenuhan dari pelunasan piutangnya.

Oleh karena itu, perlu kiranya membuat alternatif gagasan agar menjamin kepentingan pemegang fidusia, agar mendapatkan jaminan dalam hal pelusanan piutang bagi kreditur tentu harus diperhatikan. Karena pengikatan benda jaminan akan mengamankan kepentingan kreditur, begitu pula pengikatan benda jaminan fidusia akan mengamankan kepentingan kreditur atau penerima fidusia apabila kreditur wanprestasi. Dengan cara mengkaji status hukum objek jaminan fidusia tersebut.

\section{Rumusan Masalah}

Untuk memfokuskan pembahasan dalam penelitian ini, terapat dua rumusan masalah yang akan dikaji. Yakni pertama, bagaimana status hukum obyek jaminan fidusia yang dirampas oleh negera diperhitungkan sebagai pidana pembayaran uang pengganti melalui putusan pengadilan dalam perkara tindak pidana korupsi yang dilakukan oleh debitur? Kedua, bagaimana jaminan hukum terhadap pemegang hak jaminan fidusia terhadap obyek jaminan fidusia yang dirampas oleh negara diperhitungkan sebagai pidana pembayaran uang pengganti melalui putusan pengadilan dalam perkara tindak pidana korupsi yang dilakukan oleh debitur dan upaya hukumnya?

\section{Tujuan Penelitian}

Tujuan penelitian ini meliputi: pertama, untuk menganalisis status hukum obyek jaminan fidusial yang dirampas oleh negara diperhitungkan sebagai 
pidana pembayaran uang pengganti melalui putusan pengadilan dalam perkara tindak pidana korupsi yang dilakukan oleh debitur; Kedua, untuk menganalisis jaminan hukum terhadap pemegang hak jaminan fidusial terhadap obyek jaminan fidusial yang dirampas oleh negagara diperhitungkan sebagai pidana pembayaran uang pengganti melalui putusan pengadilan dalam perkara tindak pidana korupsi yang dilakukan oleh debitur.

\section{Metode Penelitian}

Metode penelitian yang digunakan dalam penelitian ini adalah penelitian normatif (normatif law research) dengan pendekatan perundang-undangan (statute approach) dan pendekatan kasus (case approcah), serta penelitian ini bersifat preskriptif, yakni mempelajari tujuan hukum, nilai-nilai keadilan, validitas aturan hukum, konsep-konsep hukum, dan norma-norma hukum. ${ }^{3}$ Bahan hukum yang dipergunakan dalam penelitian ini adalah bahan hukum primer, bahan hukum sekunder, dan bahan hukum tersier. Guna memperoleh bahan hukum yang obyektif, baik kualitas maupun kuantitas, maka metode pengumpulan bahan hukum yang dipergunakan dalam penelitian ini adalah studi kepustakaan/studi dokumenter.

Adapun analisis bahan hukum yang dipergunakan dalam penelitian ini adalah dengan menggunakan analisis secara kualitatif dengan menguraikan secara deskriptif analitis dan preskriptif. Metode analisis yang demikian ini diterapkan karena penelitian ini tidak hanya bermaksud mengungkapkan atau menggambarkan data sebagaimana adanya, tetapi juga bermaksud untuk menggambarkan bagaimana sebaiknya atau idealnya. ${ }^{4}$

\section{Hasil Penelitian dan Pembahasan}

Objek Jaminan Fidusia yang Dirampas oleh Negara untuk Diperhitungkan Sebagai Pidana Pembayaran Uang Pengganti

Putusan perkara tindak pidana korupsi pada Pengadilan Negeri Palangkaraya Nomor 35/Pid.Sus-TPK/2017/PNPlk, yang dalam perkara terdakwa Cornedy, A.Md Bin Salampak W Conrad dinyatakan terbukti bersalah

\footnotetext{
${ }^{3}$ Peter Mahmud Marzuki, Penelitian Hukum, Kencana, Jakarta, 2010, hlm. 22.

${ }^{4}$ Soerjono Soekanto, Pengantar Penelitian Hukum, Universitas Indonesia, Jakarta, 2014, hlm. 251.
} 
melanggar Pasal 8 jo Pasal 18 Undang-Undang Nomor 31 Tahun 1999 tentang Pemberantasan Tindak Pidana Korupsi jo Undang-Undang Nomor 20 Tahun 2001 Perubahan Atas Undang-Undang Nomor 31 Tahun 1999 tentang Pemberantasan Tindak Pidana Korupsi (UUPTPK). Majelis hakim menjatuhkan pidana kepada terdakwa Cornedy, A.Md Bin Salampak W Conrad berupa membayar uang pengganti sejumlah Rp. 6.276.031.233,00, serta majelis hakim menetapkan beberapa mobil yang diantaranya merupakan objek jaminan fidusia dirampas untuk negara dan diperhitungkan sebagai pembayaran uang pengganti.

Dalam contoh kasus yang lain, putusan perkara tindak pidana korupsi pada Pengadilan Negeri Manokwari Nomor 14/Pid.Sus-TPK/2014/PN.Mnk. tanggal 22 Juli 2014. Majelis hakim memutuskan bahwa objek yang menjadi jaminan fidusia tersebut disita untuk negara, sehingga mengenyampingkan hak preferensi kreditor perusahaan pembiayaan berdasarkan Pasal 27 ayat (1) UU Jaminan Fidusia dan larangan perampasan barang-barang bukan kepunyaan terdakwa dalam Pasal 19 Undang-Undang No. 31 Tahun 1999 tentang Pemberantasan Tindak Pidana Korupsi Jo. Undang-Undang Nomor 20 Tahun 2001 (UU Pemberantasan Tindak Pidana Korupsi) demi mengutamakan pengembalian kerugian negara. ${ }^{5}$

Konstruksi hukum yang ada dalam perjanjian jaminan fidusia merupakan suatu terobosan sebagai jalan untuk menjadikan benda bergerak sebagai jaminan yang tanpa perlu menyerahkan secara fisik benda tersebut kepada kreditur. Konstruksi hukum lembaga jaminan fidusia adalah dalam rangka memberikan jaminan terhadap hutang, bukan dimaksudkan untuk mengalihkan suatu hak milik atas barang jaminan. Dari konstruksi hukum jaminan fidusia ini, realitanya menimbulkan berbagai persepsi mengenai sifat, jenis, serta karakter hak fidusia, sehingga menjadikan suatu persoalan apakah hak fidusia merupakan suatu hak kebendaan (zakelijkrecht) atau sebagai hak perseorangan (persoonlijkrecht). Terhadap hal ini terdapat dua pandangan yang berbeda dari para ahli akan hal tersebut, yakni:

\footnotetext{
${ }^{5}$ Cahyadi Isman. "Kedudukan Hukum Hak Preferensial Kreditor terhadap Perampasan Objek Jaminan Fidusia dalam Kasus Korupsi (Studi Kasus Putusan Pengadilan Negeri Manokwari Nomor 14/Pid.Sus/TPK/2014/Pn.Mnk.)”, 2017, Tesis. Tangerang: Universitas Pelita Harapan, hlm. 1.
} 
1. Perjanjian fidusia merupakan perjanjian zakelijk dan memberikan hak-hak jaminan yang bersifat zakelijk bagi kreditur.

2. Perjanjian fidusia sesuai dengan asalnya menurut hukum Romawi yang disebut fiducia cum creditore yang merupakan perjanjian obligatoir dan melahirkan hak yang bersifat persoonlijk bagi kreditur. ${ }^{6}$

Pandangan pertama oleh Sri Soedewi MS, menyatakan bahwa perjanjian fidusia bersifat zakelijk, karena menurutnya pejanjian fidusia akan melahirkan hak-hak yang zakelijk dan memperoleh akibat hukum seperti halnya hak kebendaan hipotek dan gadai ketika terjadinya pailit. Berbeda dengan dengan itu Jan Jarolimek menyatakan sifat zakelijk dalam perjanjian fidusia itu terlihat seakan-akan bebas menguasai hak eigendom, namun dalam realitasnya jika terjadi pelaksanaan hak dari kreditur, maka janji-janji yang bersifat obligatoir itu tidak berlaku bagi pihak ketiga. ${ }^{7}$ Badrulzaman juga memiliki pandangan bahwa sepanjang fidusia itu tidak tunduk pada pendaftaran (yang artinya tidak terbuka untuk umum), maka perjanjian jaminan fidusia ini merupakan perjanjian dan bukan merupakan jaminan kebendaan, yaitu sebagai jaminan yang bersifat perjanjian saja, maka ia tidak mengandung akibat yang dimiliki oleh hak kebendaan. 8

Ketentuan umum tentang perampasan benda sitaan oleh negara dalam perkara tindak pidana diatur dalam Pasal 46 Undang-Undang Nomor 8 Tahun 1981 tentang Hukum Acara Pidana (selanjutnya disebut KUHAP) yang berbunyi:

1. Benda yang dikenakan penyitaan dikembalikan kepada orang atau kepada mereka dari siapa benda itu disita, atau kepada orang atau kepada mereka yang paling berhak apabila :

a. kepentingan penyidikan dan penuntutan tidak memerlukan lagi;

b. perkara tersebut tidak jadi dituntut karena tidak cukup bukti atau ternyata tidak merupakan tindak pidana;

c. perkara tersebut dikesampingkan untuk kepentingan umum atau perkara tersebut ditutup demi hukum, kecuali apabila benda itu diperoleh dari suatu tindak pidana atau yang dipergunakan untuk melakukan suatu tindak pidana.

${ }^{6}$ A. A. Andi Prajitno, Hukum Fidusia, Bayumedia, Surabaya, 2011, hlm. 6-7, dikutip dari Sri Soedewi Masjchon Sofwan, Beberapa Masalah Pelaksanaan Lembaga Jaminan Khususnya Fidusia dalam Praktek dan Pelaksanaannya di Indonesia, Fakultas Hukum Universitas Gadjah Mada, Yogyakarta, 1977, hlm. 20.

${ }^{7}$ Jan Jarolimek, Eigendom tot zakerheid, Utrecht, 1956, hlm. 84 dalam Ibid., hlm. 22.

${ }^{8}$ Mariam Darus Badrulzaman, Beberapa Permasalahan Hukum Jaminan, Jurnal Hukum Bisnis. Volume, 11, 2000, hlm. 63, dalam Gianto Al Imron, Karakteristik. Hak Jaminan Fidusia Dalam Undang-Undang Nomor 42 Tabun 1999, Tesis, Program Magister Ilmu Hukum Program Pascasarjana Universitas Airlangga, Surabaya, 2004, hlm. 18. 
2. Apabila perkara sudah diputus, maka benda yang dikenakan penyitaan dikembalikan kepada orang atau kepada mereka yang disebut dalam putusan tersebut, kecuali jika menurut putusan hakim benda itu dirampas untuk negara, untuk dimusnahkan atau untuk dirusakkan sampai tidak dapat dipergunakan lagi atau, jika benda tersebut masih diperlukan sebagai barang bukti dalam perkara lain.

Lebih lanjut di dalam Pasal 194 KUHAP menentukan bahwa:

"Dalam hal putusan pemidanaan atau bebas atau lepas dari segala tuntutan hukum, pengadilan menetapkan supaya barang bukti yang disita diserahkan kepada pihak yang paling berhak menerima kembali yang namanya tercantum dalam putusan tersebut kecuali jika menurut ketentuan undangundang barang bukti itu harus dirampas untuk kepentingan negara atau dimusnahkan atau dirusak sehingga tidak dapat dipergunakan lagi."

Untuk mengkaji status kepemilikan benda objek jaminan fidusia tersebut, diperlukan kerangka konsep dari jaminan fidusia. Menurut beberapa yurisprudensi jaminan fidusia diartikan sebagai penyerahan hak milik secara kepercayaan atas benda bergerak sebagai jaminan. ${ }^{9}$ Yang ditekankan adalah segi "penyerahan hak milik". Dalam Undang-Undang Nomor 16 Tahun 1985 tentang Rumah Susun (UU Rumah Susun), fidusia diartikan sebagai hak jaminan yang berupa penyerahan hak atas benda berdasarkan kepercayaan yang disepakati sebagai jaminan bagi pelunasan piutang kreditur. Penekanan di sini adalah "penyerahan hak". UU Rumah Susun tidak menyebutkan bahwa yang diserahkan atas benda itu adalah hak milik, melainkan secara tegas dikatakan bahwa yang diserahkan secara kepercayaan adalah "hak". Dengan demikian, pengertian hak yang diserahkan masih abstrak, belum menunjukkan kepada sesuatu hal tertentu. Jadi, yang diserahkan kepada kreditur penerima fidusia bukan terbatas pada hak milik atas benda melainkan juga hak-hak lainnya atas benda. Baik pengertian fidusia menurut yurisprudensi maupun UU Rumah Susun, keduanya memiliki hakikat penyerahan yang sama, yakni debitur pemberi fidusia menyerahkan hak milik atas benda adalah dalam fungsinya sebagai jaminan.

Berbeda halnya dalam UUJF yang membedakan arti fidusia dan jaminan fidusia. Yang dimaksud dengan fidusia menurut UUJF adalah pengalihan hak

${ }_{9}$ Mariam Darus Badrulzaman, Bab-bab Tentang Credietverband, Gadai dan Fiducia, Alumni, Bandung, 1984, hlm. 91. 
kepemilikan suatu benda atas dasar kepercayaan dengan ketentuan bahwa benda yang hak kepemilikannya dialihkan tersebut tetap dalam penguasaan pemilik benda. Fidusia di sini ditekankan kepada "pengalihan hak kepemilikan" dan "penguasaan benda jaminan tetap pada pemilik benda". Pengertian fidusia sebelum dan sesudah berlakunya UUJF, dapat disimpulkan adanya perubahan terminologi hukum yakni dan penyerahan menjadi peralihan, dan hak milik dan hak kepemilikan menjadi hak kemilikan.

Dari segi yuridis, peralihan hak mempunyai arti yang lebih luas dari penyerahan hak. Dalam terminologi hukum Eropa kontinental, dikenal istilah "transfer" dan "levering". "Transfer" diartikan sebagai pemindahan, sedangkan levering diartikan bukan saja sebagai pemindahan tetapi juga mencakup penyerahan dan peralihan. Dalam terminologi hukum anglo saxon, "transfer" diartikan sebagai an act of the parties, by which the title to property is conveyed from one person to another. ${ }^{10}$ Dapat disimpulkan bahwa penyerahan hak merupakan perbuatan hukum untuk memberikan hak secara kepercayaan, sedangkan peralihan hak adalah perbuatan hukum untuk memindahkan hak atau pergantian hak dari satu keadaan/orang tertentu kepada keadaan lain/orang lain. Peralihan hak dapat meliputi perbuatan hukum menjual, menyewakan, menjaminkan, dan sebagainya. Mengenai hak kepemilikan, dapat dijelaskan bahwa istilah tersebut kurang tepat, seharusnya UUJF menggunakan kata kemilikan sebagaimana yang diuraikan Mariam Darus Badruizaman. Lembaga hak kemilikan dikenal dengan istilah property right. Hak kemilikan diartikan sebagai hak milik dalam arti umum (luas), tidak terbatas hanya pada hak milik atas benda bergerak dan benda tidak bergerak, tetapi seluruhnya sepanjang hak kemilikan ini mempunyai objek yang diperbolehkan hukum, yaitu benda (berujud dan tidak berujud). ${ }^{11}$ Menurut peneliti istilah hak kemilikan diterjemahkan dari kata "fright of ownership". Yang dimaksud dengan kemilikan (ownership) adalah collection of rights to use and enjoy property, including right to transmit it to others. Menurut J.C. Carvan, J.V. Gooley dan EL. Mc Rae, ownership means that the owner has all the legal rights over property.

\footnotetext{
${ }^{10}$ H.C. Black, Black's Law Dictionary, Edisi ke-6, West Publishing Co, St. Paul, 1990, hlm. 1041.

${ }^{11}$ Mariam Darus Badrulzaman, Op. Cit., hlm. 43.
} 
Jadi, kata ownership lebih luas dari kata property. ${ }^{12}$ Kemilikan bukan saja menunjukkan penguasaan atau penggunaan benda tetapi juga yang lebih penting adalah titel dari benda itu.

Dalam kaitannya dengan jaminan fidusia bahwa hak kemilikan benda yang dijadikan agunan telah dialihkan kepada kreditur sebagai penerima jaminan fidusia. Artinya, alas hak (titel) dari benda itu diserahkan kepada kreditur, tetapi penguasaan (possession) benda itu secara fisik ada pada debitur pemberi jaminan fidusia. Terlihat dalam perkara tersebut di atas, pihak penerima jaminan fidusia yang merupakan kreditur atas objek jaminan fidusia adalah sebagai pemilik hak bukan berstatus sebagai pemegang hak jaminan. Sebagai pemilik hak harus diartikan sebagai pemilik jaminan atas benda bukan pemilik benda sepenuhnya dalam pengertian perjanjian jual-beli. Dari segi hukum jaminan, orang yang berkedudukan sebagai pemilik jaminan mempunyai hak-hak tertentu antara lain berhak menjaminkan kembali benda jaminan itu kepada pihak lain.

Setelah lahirnya UUJF, masalah kreditur sebagai pemilik benda jaminan fidusia, masih menimbulkan persoalan yakni kapankah momentum terjadinya kreditur penerima jaminan fidusia itu sebagai pemilik jaminan. Ada beberapa penafsiran yang dapat dicermati. Pertama, apakah momentum itu terjadi pada saat debitur pemberi fidusia menyerahkan haknya ketika mendatangani perjanjian kredit dengan jaminan fidusia. Kedua, apakah momentum itu terjadi pada saat debitur pemberi fidusia menandatangani akta jaminan fidusia di notaris. Ketiga, apakah momentum itu terjadi pada saat akta jaminan fidusia didaftarkán ke kantor fidusia. Atas problematika ini, peneliti berpendapat bahwa sebelum keluarnya UUJF, momentum terjadinya kreditur penerima fidusia sebagai pemilik benda jaminan adalah pada saat ditandatangani akta pemberian jaminan fidusia. Setelah lahirnya UUJF, momentum terjadinya kreditur penerima fidusia sebagai pemilik benda jaminan adalah pada saat akta jaminan fidusia didaftarkan di kantor pendaftaran fidusia. ${ }^{13}$

12 M. Yahya Harahap menerjemahkan kata "property" sebagai benda atau kekayaan, lihat Tan Kamelo, Hukum Jaminan Fidusia: Suatu Kebutuhan yang Didambakan, Edisi Revisi, Alumni, Bandung, 2014, hlm. 267.

13 Tan Kamelo, Op. Cit., hlm. 269. 
Untuk menentukan status objek jaminan fidusia yang dirampas oleh negara seperti perkara di atas terdapat 2 penafsiran. Penafsiran pertama dapat dilihat berdasarkan sifat-sifat objek jaminan fidusia yang mempunyai sifat Droite De Suite, kekuatan eksekutorial yang sama dengan putusan hakim yang berkekuatan hukum tetap dan jaminan fidusia ini telah didaftarkan sehingga mempunyai kepastian hukum atas suatu perjanjian fidusia termasuk objek jaminannya. Berdasarkan hal tersebut pada penafsiran pertama ini, status kepemilikan objek jaminan fidusia tetap pada penerima fidusia karena hak kebendaannya terhadap objek jaminan fidusia dapat dipertahankan.

Penafsiran kedua, akibat dari perbuatan pidana korupsi yang dilakukan pemberi jaminan fidusia sehingga dirampasnya objek jaminan fidusia tersebut oleh negara, maka status kepemilikan objek jaminan ini beralih kepada negara dan menghilangkan hak dari penerima jaminan fidusia untuk mengeksekusi benda objek jaminan fidusia apabila pemberi jaminan fidusia melakukan wanprestasi atau perbuatan melawan hukum. Karena status hak miliknya hanya sebagai pelunasan piutang saja dan hak milik dalam Pasal 570 KUHPerdata adalah hak milik yang dibatasi oleh ketentuan undang-undang, serta dapat dilihat berdasarkan kepentingannya.

Perlindungan Hukum dan Kepentingan Pemegang Hak Jaminan Fidusia atas Objek Jaminan Fidusia yang Dirampas oleh Negara sebagai Pidana Pembayaran Uang Pengganti dalam Perkara Tindak Pidana Korupsi dan Upaya Hukumnya

Pasal 1131 KUHPerdata menyebutkan segala harta kekayaan seseorang debitur baik yang berupa benda-benda bergerak maupun benda-benda tetap, baik yang sudah ada maupun yang baru akan ada di kemudian hari, menjadi jaminan bagi semua perikatan utangnya. Jadi berdasarkan ketentuan dalam pasal tersebut maka sebenarnya sudah terdapat pemberian jaminan oleh seorang debitur kepada setiap krediturnya dengan semua kekayaan debitur itu. Namun, pola jaminan yang dirumuskan dalam Pasal 1131 KUHPerdata ini kurang memberikan kedudukan yang kuat bagi kreditur. Kelemahan posisi kreditur ini diberikan jalan keluar oleh Pasal 1132 KUHPerdata, yang mana dalam pasal ini ditegaskan bahwa: 
"Kebendaan tersebut menjadi jaminan bersama-sama bagi semua orang yang mengutangkan padanya; pendapatan penjualan benda-benda itu dibagi-bagi menurut keseimbangan, yaitu menurut besar-kecilnya piutang masingmasing, kecuali apabila di antara para berpiutang itu ada alasan-alasan yang sah untuk didahulukan".

Ketentuan dalam Pasal 1132 KUHPerdata tersebut mengandung asas bahwa para kreditur akan memperoleh pelunasan piutang secara seimbang dari debitur. Namun asas ini tidak belaku apabila di antara para kreditur terdapat alasanalasan yang sah untuk didahulukan dalam memperoleh pelunasan piutang. Kedudukan preferen kreditur itu diperoleh antara lain apabila mereka memiliki hak kebendaan.

Hak kebendaan itu lahir apabila kreditur mendukung perjanjian hutang piutangnya dengan perjanjian kebendaan. Perjanjian ini dilakukan dengan cara mengikat benda milik debitur. Perjanjian jaminan kebendaan merupakan hak mutlak atas suatu benda tertentu yang dijadikan objek jaminan untuk suatu ketika dapat diuangkan bagi pelunasan atau pembayaran hutang apabila debitur melakukan wanprestasi. ${ }^{14}$

Sehubungan dengan prinsip memberikan kepastian hukum, maka UUJF mengambil prinsip pendaftaran jaminan fidusia. Manfaat perjanjian fidusia dilakukan secara tertulis adalah bahwa kreditur pemegang jaminan fidusia demi kepentingannya akan menuntut cara yang paling gampang untuk membuktikan adanya penyerahan jaminan tersebut terhadap debitur. Hal paling penting untuk mengantisipasi kemungkinan terjadinya hal-hal di luar keinginan kita. Tanpa akte yang sah akan sulit bagi kreditur untuk membuktikan hak-haknya. Dengan akte akan dapat dicantumkan janji-janji khusus antar debitur dan kreditur yang mengatur hubungan hukum diantara mereka. Pendaftaran tersebut diharapkan memberikan kepastian hukum kepada pemberi dan penerima fidusia maupun kepada pihak ketiga, yang pada umumnya dimaksudkan untuk memberikan suatu posisi yang kuat bagi kreditur dan nantinya sesudah didaftarkan dimaksudkan untuk juga mengikat pihak ketiga.

${ }^{14}$ Djuahenda Hasan, Lembaga Jaminan Kebendaan Bagi Tanah dan Benda Lain yang Melekat pada Tanah dalam Konsepsi Penerapan Asas Pemisahan Horisontal, Cetakan Ke-2, Citra Aditya Bakti, Bandung, 2011, hlm. 236. 
Deskripsi di atas terlihat bahwa para pihak dalam sebuah perjanjian jaminan fidusia, baik penerima jaminan fidusia maupun pemberi jaminan fidusia menurut UUJF sama-sama diberikan perlindungan hukum. Sebagaimana dikemukakan Satjipto Raharjo ${ }^{15}$ perlindungan hukum bertujuan memberikan pengayoman terhadap hak asasi manusia (HAM) yang dirugikan orang lain dan perlindungan itu diberikan kepada masyarakat agar dapat menikmati semua hak-hak yang diberikan oleh hukum. Karena sifat sekaligus tujuan hukum menurutnya adalah memberikan perlindungan (pengayoman) kepada masyarakat, yang harus diwujudkan dalam bentuk adanya kepastian hukum. Dalam hal ini, kedua belah pihak bagi pemberi perlindungan berupa adanya hak pakai atas benda jaminan, dan wanprestasi pemberi jaminan fidak akan menyebabkan benda jaminan dengan UUJF adalah diberikannya hak preferent atas piutangnya, dan berlakunya asas droit de suite atas benda jaminan, bagi pihak ketiga asas publisitas dalam perjanjian jaminan fidusia akan memberikan informasi terhadap benda-benda yang difidusiakan.

Lebih lanjut, perlindungan hukum dan kepentingan kreditur dapat dilihat pada Pasal 20 UUJF, yang berbunyi:

“Fidusia tetap mengikuti Benda yang menjadi objek Jaminan fidusia dalam tangan siapapun Benda tersebut berada, kecuali pengalihan atas benda tersebut, kecuali pengalihan atas benda persediaan yang menjadi objek Jaminan Fidusia".

Ketentuan tersebut menegaskan bahwa jaminan fidusia mempunyai sifat kebendaan dan berlaku terhadapnya asas droit de suite, kecuali pengalihan atas benda persediaan yang menjadi objek jaminan fidusia. Perlindungan yang sama juga dapat dilihat dalam Pasal 23 ayat (2) UUJF, yang berbunyi:

"Pemberi Fidusia dilarang mengalihkan, menggadaikan, atau menyewakan kepada pihak lain benda yang menjadi objek jaminan fidusia yang tidak merupakan benda persediaan, kecuali dengan persetujuan tertulis terlebih dahulu dari penerima fidusia".

Sanksi terhadap ketentuan di atas adalah pidana, sebagaimana dimaksud dalam Pasal 36 UUJF, yang berbunyi: 
"Pemberi Fidusia yang mengalihkan, menggadaikan atau menyewakan Benda yang menjadi objek Jaminan Fidusia sebagaimana dimaksud dalam Pasal 23 ayat (2) yang dilakukan tanpa persetujuan tertulis terlebih dahulu dari Penerima Fidusia, dpidana dengan pidana penjara paling lama 2 (dua) tahun dan denda paling banyak Rp. 50.000 .000 (lima puluh juta rupiah).

Atas segala tindakan dan kelalaian pemberi fidusia, penerima fidusia, berdasarkan karena kelalaian tersebut tidak bertanggung jawab, sebagaimana dimaksud dalam Pasal 24 UUJF, yang berbunyi:

"Penerima Fidusia tidak menanggung kewajiban atas akibat tindakan atau kelalaian Pemberi Fidusia baik yang timbul dari hubungan kontraktual atau yang timbul dari perbuatan melanggar hukum sehubungan dengan penggunaan dan pengalihan Benda yang menjadi objek Jaminan Fidusia".

Pada intinya maksud/tujuan dari perjanjian jaminan fidusia dari segi perlindungan hukum bagi penerima jaminan fidusia adalah memberikan hak istimewa atau hak didahulukan baginya guna pelunasan hutang-piutang, debitur padanya (asas schuld dan haftung).

Lebih lanjut perlindungan hukum terhadap hak atas piutang yang didahulukan dapat dilihat pada ketentuan Pasal 27 UUJF, yang berbunyi:

(1)Penerima Fidusia memiliki hak yang didahulukan terhadap kreditur lainnya.

(2)Hak didahulukan sebagaimana, dimaksud dalam ayat (1) adalah hak Penerima Fidusia untuk mengambil pelunasan piutangnya atas hasil eksekusi Benda yang menjadi objek Jaminan Fidusia.

(3)Hak yang didahulukan dan Penerima Fidusia tidak hapus karena adanya kepailitan dan atau likuidasi Pemberi Fidusia.

Secara keseluruhan maka, beberapa hal yang dapat menunjukkan adanya perlindungan hukum terhadap penerima jaminan fidusia menurut UUJF antara lain sebagai berikut:

1. Adanya lembaga pendaftaran jaminan fidusia, yang tidak lain adalah untuk menjamin kepentingan pihak yang menerima jaminan fidusia;

2. Adanya larangan pemberi jaminan fidusia untuk memfidusiakan ulang objek jaminan fidusia (Pasal 17);

3. Adanya ketentuan bahwa pemberi jaminan fidusia tidak diperbolehkan untuk mengalihkan, menggadaikan atau menyewakan (Pasal 23 Sub 2);

4. Adanya ketentuan pemberi jaminan fidusia wajib menyerahkan benda jaminan, kalau kreditur hendak melaksanakan eksekusi atas objek jaminan fidusia;

5. Adanya ketentuan pidana dalam Undang-Undang Jaminan Fidusia. 
Lebih lanjut, pengikatan jaminan fidusia antara debitur dan kreditur harus dipandang sebagai suatu itikad baik dari kreditur yang tidak mengetahui bahwa objek jaminan fidusia tersebut diperoleh debitur dari perbuatan melawan hukum dengan melakukan tindak pidana korupsi. Oleh karena itu kreditur pemegang jaminan fidusia yang beritikad baik wajib dilindungi oleh hukum yang berlaku. Namun demikian bila tindakan debitur dalam melakukan pengikatan jaminan fidusia terhadap kreditur terindikasi merupakan suatu itikad tidak baik untuk menyelamatkan harta bendanya yang diperoleh dari hasil kejahatan, khususnya tindak pidana korupsi dari penyitaan yang dilakukan pengadilan, maka benda yang telah diikat dengan jaminan fidusia tersebut dapat saja disita oleh penyidik atas penetapan pengadilan karena merupakan suatu barang bukti hasil kejahatan yang wajib diamankan oleh pihak yang berwajib. ${ }^{16}$

Sebagaimana disebutkan di dalam Pasal 19 UUPTPK, yang berbunyi:

(1)Putusan pengadilan mengenai perampasan barang-barang bukan kepunyaan terdakwa tidak dijatuhkan, apabila hak-hak pihak ketiga yang beritikad baik akan dirugikan.

(2)Dalam hal putusan pengadilan sebagaimana dimaksud dalam ayat (1) termasuk juga barang pihak ke yang mempunyai itikad baik maka pihak ketiga tersebut dapat mengajukan surat keberatan kepada pengadilan yang bersangkutan dalam waktu paling lambat 2 (dua) bulan setelah putusan pengadilan diucapkan di sidang terbuka untuk umum.

(3)Pengajuan surat keberatan sebagaimana dimaksud dalam ayat (2) tidak menangguhkan atau menghentikan pelaksanaan putusan pengadilan.

(4)Dalam keadaan sebagaimana dimaksud dalam ayat (2) tidak menangguhkan atau menghentikan pelaksanaan putusan pengadilan.

(5)Penetapan hakim atas surat keberatan sebagaimana dimaksud dalam ayat (2) dapat dimintakan kasasi ke Mahkamah Agung oleh pemohon atau penuntut umum.

Atas ketentuan undang-undang yang mengharuskan perampasan terhadap benda sitaan yang berasal dari tindak pidana korupsi, lalu bagaimana perlindungan hukum bagi penerima jaminan fidusia? Bukankah menurut Pasal 20 UUJF, yang berbunyi:

"Jaminan Fidusia tetap mengikuti Benda yang menjadi objek jaminan Fidusia dalam tangan siapapun Benda tersebut berada, kecuali pengalihan atas benda persediaan yang menjadi objek Jaminan Fidusia."

${ }^{16}$ Irsan Nawawi, Penyitaan dalam Hukum Perdata dan Hukum Pidana, Pustaka Ilmu, Jakarta, 2007, hlm. 46. 
Kemudian diperkuat kembali oleh Pasal 24 UUJF yang berbunyi:

"Penerima Fidusia tidak menanggung kewajiban atas akibat tindakan atau kelalaian Pemberi Fidusia baik yang timbul dan hubungan kontraktual atau yang timbul dari perbuatan melanggar hukum sehubungan dengan penggunaan dan pengalihan Benda yang menjadi objek Jaminan Fidusia."

Bagaimanapun juga penerima jaminan fidusia tetap mendapat perlindungan hukum termasuk dalam hal undang-undang yang bersifat khusus seperti UUPTPK yang mengharuskan negara melakukan perampasan terhadap objek jaminan fidusia. Lagipula, dalam hal terjadi perampasan benda jaminan fidusia oleh negara akibat benda jaminan fidusia tersebut berasal dari tindak pidana korupsi, perjanjian jaminan fidusia tidak hapus dengan sendirinya. Menurut Pasal 25 ayat (1) UUJF, hanya ada 3 hal yang menyebabkan jaminan fidusia hapus, yakni:

a. Hapusnya utang yang dijamin dengan fidusia;

b. Pelepasan hak atas Jaminan Fidusia oleh Penerima Fidusia; atau

c. Musnahnya Benda yang menjadi obyek Jaminan Fidusia.

Benda jaminan fidusia yang dirampas oleh negara tidak dapat diartikan bahwa bendanya musnah sebagaimana ketentuan huruf c diatas. Pengertian musnah disini adalah tidak ada lagi wujud bendanya. Sementara dalam hal bendanya dirampas oleh negara, secara materiil bendanya masih ada, hanya saja secara yuridis tidak lagi berada dalam penguasaan penerima jaminan fidusia dan tidak dapat lagi diambil lagi dari kekuasaan negara. ${ }^{17}$

Adapun wujud perlindungan hukum terhadap pihak ketiga, termasuk terhadap pemegang jaminan fidusia agar haknya dapat dipertahankan meskipun benda yang dijadikan objek jaminan fidusia tetap dirampas untuk negara, maka penerima jaminan fidusia dapat menggunakan instrumen hukum acara perdata yang di dalam KUHAP sendiri telah disediakan landasan hukumnya sebagaimana ketentuan Pasal 98 KUHAP yang berbunyi:

17 Rasyid Yuliansyah, 2019, Perlindungan Hukum Terhadap Penerimaan Fidusia Ketika Benda Yang Diterimanya Sebagai Jaminan Piutang Dirampas Untuk. Negara Karena Telah Digunakan Sebagai Sarana Tindak Pidana Kejahatan. Artikel dalam https://doktorhukum.com/perlindungan-hukum-terhadap-penerimaan-fidusia-ketika-benda-yangditerimanya-sebagai-jaminan-piutang-dirampas-untuk-negara-karena-telah-digunakan-sebagai-sarana-tindakpidana-kejahatan/ diakses tanggal 17 Maret 2021. 
(1)Jika suatu perbuatan yang menjadi dasar dakwaan di dalam suatu pemeriksaan perkara pidana oleh pengadilan negeri menimbulkan kerugian bagi orang lain, maka hakim ketua sidang atas permintaan orang itu dapat menetapkan untuk menggabungkan perkara gugatan ganti kerugian kepada perkara pidana itu.

(2)Permintaan sebagaimana dimaksud dalam ayat (1) hanya dapat diajukan selambat-lambatnya sebelum penuntut umum mengajukan tuntutan pidana. Dalam hal penuntut umum tidak hadir, permintaan diajukan selambat-lambatnya sebelum hakim menjatuhkan putusan.

Adapun yang menjadi pertanyaan mengenai siapa yang digugat? Tentunya yang digugat adalah terdakwa yang selaku pemberi jaminan fidusia yang mana objek benda jaminan fidusia kepada penerima jaminan fidusia yang berasal dari tindak pidana. Dalam hal benda sitaan (objek jaminan fidusia) pasti akan dirampas untuk negara, tentunya Gugatan itu dimaksudkan agar si terdakwa dalam kapasitasnya sebagai Tergugat dinyatakan telah melakukan Perbuatan Melawan Hukum (Onrechtmatigedaad), sehingga terdakwa (si tergugat) diharuskan mengganti kerugian yang nilainya seimbang dengan benda yang telah dirampas oleh negara ditambah biaya yang telah dikeluarkan oleh pihak yang dirugikan tersebut. 18

Penggabungan gugatan ini ke dalam perkara pidana tidak akan mengacaukan Hukum Acara Pidana itu sendiri, sebagaimana Pasal 101 KUHAP secara tegas menentukan hal tersebut. Dengan begitu, Pihak Ketiga (termasuk penerima jaminan fidusia) dalam gugatannya dapat pula sekalian meminta kepada Majelis Hakim agar benda milik Tergugat (diluar benda yang disita dalam perkara pidana) dilakukan sita jaminan (conservatoir beslag) supaya pihak ketiga (penerima jaminan fidusia) lebih terjamin pemulihan haknya.

Apabila gugatan Pihak Ketiga (termasuk penerima jaminan fidusia) pada penggabungan dalam perkara pidana tersebut dikabulkan, maka sebagai tindakan akhir pemulihan haknya (setelah putusan berkekuatan hukum tetap) dilakukanlah eksekusi terhadap benda sita jaminan yang telah dimintakan sebelumnya. Untuk pelaksanaan putusannya berlakulah ketentuan Pasal 195 sampai dengan Pasal 200 H.I.R. 
Dalam praktik hukum, terkadang Pihak Ketiga, termasuk penerima jaminan fidusia menempuh upaya hukum berupa Perlawanan Pihak Ketiga (Derden Verzet). Terlepas apapun putusan Hakim yang memeriksa dan mengadili gugatan Perlawanan Pihak Ketiga (Derden Verzet), menurut peneliti upaya hukum tersebut tidak tepat diterapkan dalam upaya mempertahankan benda hak milik pihak ketiga ketika terjadi penyitaan dalam perkara pidana. Kaidah hukum yang mengatur tentang gugatan Perlawanan Pihak Ketiga (Derden Verzet) terdapat di dalam H.I.R. Berdasarkan ketentuan Pasal 195 ayat (1) H.I.R, yang berbunyi:

“Keputusan hakim dalam perkara yang pada tingkat pertama diperiksa oleh pengadilan negeri, dilaksanakan atas perintah dan di bawah pimpinan ketua pengadilan negeri yang memeriksa perkara itu, menurut cara yang diatur dalam pasal-pasal berikut." (Rv. 350, 360; IR. 194.).

Kemudian pada Pasal 195 ayat (6) H.I.R menyatakan bahwa:

"Jika pelaksanaan keputusan itu dilawan, juga perlawanan itu dilakukan oleh orang lain yang mengakui barang yang disita itu sebagai miliknya, maka hal itu serta segala perselisihan tentang upaya paksa yang diperintahkan itu, diajukan kepada dan diputuskan oleh pengadilan negeri yang dalam daerah hukumnya harus dilaksanakan keputusan itu tiap dua kali dua puluh".

Masih terkait dengan Pasal 195 H.I.R diatas, selanjutnya menurut Pasal 207 ayat (1) H.I.R dinyatakan:

"Perlawanan debitur terhadap pelaksanaan keputusan, baik dalam hal disitanya barang tak bergerak maupun dalam hal disitanya barang bergerak, harus diberitahukan oleh orang itu dengan surat atau dengan lisan kepada ketua pengadilan negeri tersebut pada pasal 195 ayat (6); jika perlawanan itu diberitahukan dengan lisan, maka ketua wajib mencatatnya atau menyuruh mencatatnya". (IR. 120, 197, 206.)

Semua ketentuan yang ada dalam pasal-pasal H.I.R. yang dikutip diatas, dapat dipastikan bahwa isinya mengatur tentang perkara perdata, bukan perkara pidana. Dengan begitu, keputusan hakim yang dimaksud pada awal kalimat Pasal 195 ayat (1) H.I.R. "Keputusan hakim dalam perkara yang pada tingkat pertama diperiksa oleh pengadilan negeri..." menunjukkan bahwa keputusan hakim yang dimaksud adalah keputusan dalam perkara perdata, termasuk penyitaan maupun eksekusi atas benda sitaannya berasal dari perkara perdata, 
sehingga perlawanan yang dimaksud dalam Pasal 195 ayat (6) H.I.R adalah perlawanan pihak ketiga terhadap tindakan penyitaan dalam perkara perdata.

Sebagai penguat atas tafsir dari Pasal 195 H.I.R., dapat diperhatikan lagi pada bunyi awal kalimat Pasal 207 H.I.R. "Perlawanan debitur terhadap pelaksanaan keputusan...". Kata "debitur" ialah bermakna pihak yang berhutang ke pihak lain dengan menerima sesuatu dari kreditur yang dijanjikan debitur untuk dibayar kembali pada masa yang akan datang. Hal ini menunjukkan bahwa debitur terikat dengan suatu perjanjian atas utang yang dibuatnya terhadap kreditur, sedangkan perjanjian tersebut pengaturannya merupakan domain daripada hukum perdata karena sifat hubungan hukumnya hanya sebatas antar subjek hukum, bukan subjek hukum dengan publik sebagaimana halnya hukum publik.

Terlihat jelas bahwa Gugatan Perlawanan Pihak Ketiga (Derden Verzet) hanya berlaku dalam hal suatau perkara yang dilawan adalah perkara perdata, sehingga tidak dapat diterapkan untuk melakukan perlawanan terhadap penyitaan benda milik pihak ketiga dalam perkara pidana. Saluran hukum yang dapat digunakan dan telah disediakan oleh pembentuk undang-undang bagi kepentingan pihak ketiga mempertahankan haknya dalam hal benda miliknya di sita dalam perkara pidana adalah melalui upaya gugatan biasa sebagaimana ditentukan diatur dalam Pasal 98 KUHAP.

Berdasarkan pembahasan di atas dapat dikatakan bahwa penerima jaminan fidusia dilindungi oleh hukum, meskipun benda yang menjadi jaminan piutangnya dirampas untuk negara sebagai pembayaran uang pengganti dalam tindak pidana korupsi karena objek yang dijadikan jaminan fidusia tersebut berasal dari tindak pidana korupsi yang dilakukan oleh pemberi jaminan fidusia. Perlindungan hukum terhadap pemegang jaminan fidusia tersebut didasarkan pada ketentuan Pasal 98 KUHAP yang pelaksanaannya adalah dengan cara mengajukan gugatan perdata kepada pihak yang merugikannya, bukan kepada negara, khusus dalam perkara tindak pidana korupsi. 


\section{Penutup}

Dari uraian di atas dapat diperoleh kesimpulan, pertama, perampasan oleh negara terhadap objek jaminan fidusia yang diperhitungkan sebagai pembayaran uang pengganti dalam perkara tindak pidana korupsi terdapat 2 penafsiran untuk menentukan status objek jaminan fidusia yang dirampas oleh negara. Penafsiran pertama dapat dilihat berdasarkan sifat-sifat objek jaminan fidusia yang mempunyai sifat Droite De Suite, dimana status kepemilikan objek jaminan fidusia tetap pada penerima fidusia karena hak kebendaannya terhadap objek jaminan fidusia dapat dipertahankan. Penafsiran kedua, akibat dari perbuatan pidana korupsi yang dilakukan pemberi jaminan fidusia sehingga dirampasnya benda yang menjadi objek jaminan fidusia tersebut oleh negara ini maka status kepemilikan objek jaminan ini beralih kepada negara dan menghilangkan hak dari penerima jaminan fidusia untuk mengeksekusi benda objek jaminan fidusia.

Kedua, jaminan hukum terhadap pemegang jaminan fidusia terlihat dengan adanya lembaga pendaftaran jaminan fidusia untuk menjamin kepentingan pihak yang menerima jaminan fidusia; adanya larangan pemberi jaminan fidusia untuk memfidusiakan ulang objek jaminan fidusia, tidak diperbolehkan untuk mengalihkan, menggadaikan atau menyewakan objek jaminan fidusia; adanya ketentuan pemberi jaminan fidusia wajib menyerahkan benda jaminan, kalau kreditur hendak melaksanakan eksekusi atas objek jaminan fidusia; adanya ketentuan pidana dalam UUJF. Ketika objek jaminan fidusia dirampas oleh negara perlindungan hukum terhadap pemegang jaminan fidusia tersebut didasarkan pada ketentuan Pasal 98 KUHAP yang pelaksanaannya adalah dengan cara mengajukan gugatan perdata kepada pihak yang merugikannya, bukan kepada negara, khusus dalam perkara tindak pidana korupsi.

\section{Daftar Pustaka}

\section{Buku}

A. A. Andi Prajitno, Hukum Fidusia, Bayumedia, Surabaya, 2011.

Bayumedia Black, H.C., Black's Law Dictionary, Edisi ke-6, West Publishing Co, St. Paul, 1990.

Darus Badrulzaman, Mariam, Bab-bab Tentang Credietverband, Gadai dan Fiducia, Alumni, Bandung, 1984. 
Hasan, Djuahenda, Lembaga Jaminan Kebendaan Bagi Tanah dan Benda Lain yang Melekat pada Tanah dalam Konsepsi Penerapan Asas Pemisahan Horisontal. Cetakan Ke-2, Citra Aditya Bakti, Bandung, 2011.

Kamelo, Tan, Hukum Jaminan Fidusia: Suatu Kebutuhan yang Didambakan, Edisi Revisi, Alumni, Bandung, 2014.

Mahmud Marzuki, Peter, Penelitian Hukum, Kencana, Jakarta, 2010.

Nawawi, Irsan, Penyitaan dalam Hukum Perdata dan Hukum Pidana, Pustaka Ilmu, Jakarta, 2007.

Soedewi Masjchon Sofwan, Sri, Beberapa Masalah Pelaksanaan Lembaga Jaminan Khususnya Fidusia dalam Praktek dan Pelaksanaannya di Indonesia, Fakultas Hukum Universitas Gadjah Mada, Yogyakarta, 1977.

Soekanto, Soerjono, Pengantar Penelitian Hukum, Universitas Indonesia, Jakarta, 2014.

Waluyo, Bambang, Penelitian Hukum Dalam Praktek, Cetakan Ke-3, Sinar Grafika, Jakarta, 2002.

\section{Jurnal}

I Made Sarjana, Desak Putu Dewi Kasih, dan I Gusti Ayu Kartika, Menguji Asas Droit De Suit Dalam Jaminan Fidusia, Udayana Master Law Journal Vol. 4 No.

3. September 2015, Magister Hukum Udayana Denpasar.

Mariam Darus Badrulzaman, "Beberapa Permasalahan Hukum Jaminan”, Jurnal Hukum Bisnis, Volume. 11. 2000.

\section{Tesis}

Al Imron, Gianto, Karakteristik Hak Jaminan Fidusia Dalam Undang-Undang Nomor 42 Tahun 1999, Tesis Program Magister Ilmu Hukum Program Pascasarjana Universitas Airlangga Surabaya, 2004.

Isman, Cahyadi. "Kedudukan Hukum Hak Preferensial Kreditor terhadap Perampasan Objek Jaminan Fidusia dalam Kasus Korupsi (Studi Kasus Putusan Pengadilan Negeri Manokwari Nomor 14/Pid.Sus/TPK/2014/Pn.Mnk.)", 2017, Tesis, Tangerang: Universitas Pelita Harapan.

\section{Perundang-undangan}

Kitab Undang-Undang Hukum Perdata.

Kitab Undang-Undang Hukum Pidana.

Kitab Undang-Undang Hukum Acara Pidana.

Mahkamah Agung. Peraturan Mahkamah Agung Nomor 5 Tahun 2014 tentang Pidana Tambahan Uang Pengganti dalam Tindak Pidana Korupsi;

Republik Indonesia. Undang-Undang Nomor 31 Tahun 1999 tentang Pemberantasan Tindak Pidana Korupsi. 
Republik Indonesia.Undang-Undang Nomor 42 Tahun 1999 tentang Jaminan Fidusia.

Republik Indonesia. Undang-Undang Nomor 20 Tahun 2001 tentang Perubahan atas Undang-Undang Nomor 31 Tahun 1999 tentang Pemberantasan Tindak Pidana Korupsi;

\section{Putusan Pengadilan}

Putusan Pengadilan Negeri Palangkaraya Nomor 35/Pid.Sus-TPK/2017/PNPlk.

\section{Surat Edaran}

Jaksa Agung. Surat Edaran Jaksa Agung Nomor B-020/A/J.A/04/2009 tentang Tata Cara Penyelesaian Denda dan Uang Pengganti dalam Perkara Tindak Pidana Korupsi.

\section{Internet}

Rasyid Yuliansyah, 2019, Perlindungan Hukum Terhadap Penerimaan Fidusia Ketika Benda Yang Diterimanya Sebagai Jaminan Piutang Dirampas Untuk Negara Karena Telah Digunakan Sebagai Sarana Tindak Pidana Kejahatan. Artikel dalam https://doktorhukum.com/perlindungan-hukum-terhadappenerimaan-fidusia-ketika-benda-yang-diterimanya-sebagai-jaminanpiutang-dirampas-untuk-negara-karena-telah-digunakan-sebagai-saranatindak-pidana-kejahatan/ diakses tanggal 17 Maret 2021. 